\title{
TEHETSÉGGONDOZÁS, VIZUALITÁS ÉS KÖRNYEZETI NEVELÉS
}

\author{
Szerzők: \\ Vályi Péter \\ Eszterházy Károly Egyetem
}

Szerző e-mail címe:

valyipeti@gmail.com
Lektorok:

Varga Attila

Eszterházy Károly Egyetem - OFI

Mező Katalin (PhD)

Debreceni Egyetem

...és további két anonim lektor

\begin{abstract}
Absztrakt
A környezeti neveléssel foglalkozó szakirodalmak ajánlások, stratégiák egész tárházát szolgáltatják számunkra. Ezek a megközelítések széles skálán mozognak az oktatás-nevelés tereinek megválasztásában, stimulálandó attitűdök vonatkozásában. Egyvalamiben azonban mégis egyezést mutatnak, méghozzá abban, hogy a közös ügyünk csak akkor vihető véghez sikeresen, ha az oktatás területén tevékenykedő összes ágens együttesen lép fel és integrálja saját szakterületén a környezet kérdését.
\end{abstract}

Kulcsszavak: tehetséggondozás, iskolakert, környezeti nevelés, vizuális nevelés

Diszciplina: pedagógia

\section{Abstract}

\section{TALENT DEVELOPMENT, VISUALITY AND ENVIRONMENTAL EDUCATION}

The literature of enviromental education provides a long list of recommendations and strategies for us. These approaches are developing rapidly across a wide range of areas within the educational field, all with the aim of producing positive attitudes. Despite all these different approaches there is a point which is shared by them all; i.e. that the whole community of the teachers has to collaborate to reach a common goal which needs to integrate the question of environmental education into our pedagogical practice.

Keywords: talent management, school garden, environmental education, visual education

Discipline: pedagogy

Vályi Péter (2019): Tehetséggondozás, vizualitás és környezeti nevelés. OxIPO - interdiszciplináris tudományos folyóirat, 2019/2, 101-107. doi: 10.35405/OXIPO.2019.2.101 


\section{Bevezetés / a gyakorlat elméleti keretezése}

Brian Holmes esztéta és kultúrakritikus szerint, az az igazán érdekes, és releváns mûvészet ökológiai kihívások egész sorával megbirkózni kényszerülő társadalmainkban, ami valódi cselekvés formájában manifesztálódik. Továbbá közvetlenül a társadalmi történésekbe, annak dinamikájába csatornázódik (Varga, 2016). Ez az állítás, még, ha vitatható is múvészetelméleti, piaci, kereskedelmi szempontok mentén, megfeleltethetô Jensen \& Schnack nevelési cselekvési kompetencia koncepciójának, amely hasonló analógián, az eddig megszokotthoz viszonyítva, radikális paradigmaváltást javasol univerzálisan az oktatás-és neveléstudománynak, azon belül is a környezeti nevelésnek. Felfogásuk szerint az oktatást új alapokra kell helyezni, ahol a cselekvés, mint kulcskompetencia kell, hogy középpontba kerüljön, domináns fejlesztendő készségként. (Jensen, Schnack 1997) Ugyanakkor, csak, hogy gazdagítsuk az egybeesések számát, David W. Orr akadémikus, környezeti nevelés kutató is hasonló szükségszerű módosítások végrehajtását sürgeti, meghivatkozva Barry Lopez szavait, amik elmarasztalók, modern társadalmainkkal szemben, főként a helyi környezeti ismereteink, kézi szerszámaink használatában való jártasságunk, lakóhelyeinkhez való kötődésünk tekintetében. Az Orr által lehetséges válaszként kifejtett fejlesztési keretrendszer kevésbé direkt, akció alapú, óvatos, de lényegét tekintve szintén a kint és bent dichotómiájának meghaladását támogatja „a valódi világtól” való elzárkózottság ellenében (Orr 1998, in Takács-Sánta 2007).

A környezeti neveléssel foglalkozó szakirodalmak ajánlások, stratégiák egész tárházát szolgáltatják számunkra. Bár ezek a szakirodalmak széles skálán mozognak az oktatás-nevelés tereinek megválasztásában, stimulálandó attitűdök vonatkozásában, egy valamiben azonban mégis egyezést mutatnak, méghozzá abban, hogy ez a közös ügyünk csak akkor vihető véghez sikeresen, ha az oktatás területén tevékenykedő összes ágens együttesen lép fel és integrálja saját szakterületén a környezet kérdését (NKNS, 2013). Az előbbi ajánlás, vagy pedagógus társadalomhoz intézett felhívás korán sem egyenlő a produktivizmus szellemiségében készített hírek kiüresített üzeneteivel, hiszen a tét nem ke- vesebb, mint az emberiség sorsa és életben maradása a Föld nevú bolygón (Varga 2007, Vida 2012). A pedagógus közösségünk legfőbb feladata talán elsősorban ebben nyilvánul meg: gondosan ügyelni arra, hogy a probléma ne veszítsen jelentőségéből, ne devalválódjon, továbbá felfedni azokat az antagonizmusokat, amelyek sok esetben eleve a magatehetetlenségre predesztinálnak minket, ezeken felül lehetőséget, stratégiát kell szolgáltatnunk a diákok számára.

A tanulmány témájául választott gyakorlat ezekre az aktuális elméleti keretekre fókuszálva próbál meg a komplexitás és transzdiszciplinaritás segítségével reagálni. A múvészeti iskolába járó tanulók tehetséggondozásán túl egy olyan projektfeladat létrehozása volt a célunk, amely nemcsak új ismeretek elsajátítását biztosítja, hanem azok más területeken való alkalmazását is lehetővé teszi az megszerzett ismeret, személyesen megélt tapasztalat absztrahálásán keresztül.

A gyakorlat és a köré épülő kutatás jellemzően balti országokban végzett, MUVIN projekthez kapcsolódik (Action Competence, Conflicting Interests and Environmental Education, 2003).

\section{Fogalmak}

Tehetséggondozás: A tehetség nagytudású egyén, akit folyamatos cselekvésvágy, naiv érdeklődés, nyitottság jellemez (Czeizel, 1997). Tehetséggondozás, vagy tehetségfejlesztés az, amikor a kötelező ismeretek, tananyagok ismeretén, elsajátításán túl történik fejlesztés, másszóval gazdagítás (Passow, 1958).

Iskolakert: Az iskolakert jelentésmezőjének sokrétű megközelítési lehetőségének ellenére, célszerű kísérletet tenni egy általános definíció megalkotására, amely nem az egyes hozzárendelt speciális célokra fókuszál, hanem általánosságban próbálja meg megragadni az iskolakert fogalmát. Ennek megfelelően az iskolakert egy olyan mesterségesen létrehozott féltermészetes tér az iskola egészén belül, ahol változatos oktató-neveló munka zajlik (Winkel 1997, Iskolakertekért Alapítvány 2018).

Vizuális nevelés: A vizuális nevelés célja a vizuális befogadás, megismerés, a vizuális kommunikáció eszközeinek magabiztos ismerete és használata, valamint 
esztétikai szemléletformálás. Ezen felül egy komplex szakmai ismeretanyag átadása, amely segítséget nyújt a múvészettörténeti korszakok, stílusjegyeinek, szignifikáns alkotásainak értelmezésében, kontextualizálásában (Liebermann, 2009).

Környezeti nevelés: A környezeti nevelés egy átfogó nevelési stratégia, amely nem azonos a természettudományok oktatásával. Direkt és indirekt formában felelősségkész és környezeti, természeti ügyeinkkel szemben érzékeny közösségek létrehozása az egyének attitűdjeinek stimulálásán keresztül (Mágori, 2001).

\section{Az IPOO modell alkalmazása a gyakorlat során}

Az IPOO modell, mint tanulási stratégia tökéletesen illeszkedik a projektfeladat eredeti koncepciójához. Az input, tehát a bemeneti fázis a formális és nonformális ismeretszerzés szakaszával egyenlő, ahol a diákok a projektek megvalósításához szükséges ismereteket sajátíthatják el. A process, tehát maga a feldolgozó szakasz a tanultak gyakorlati alkalmazása, divergens gondolkodás, problémamegoldás felhalmozott fizikai és nem fizikai eszközkészlet kreatív alkalmazása és az objektek elkészítése. Az output, vagy outputok, maguk a kész, képzőművészeti inaktivitásukból kiszakított madárházak, madáretetők, mint a tanulási folyamat érzékelhetó és értékelhető produktumai. A sikeres projektfeladat nélkülözhetetlen előfeltétele a szervezés a rendelkezésre álló időkeret meghatározása, jelen esetben az egyes munkafolyamatok idôrendi sorrendbe állítása és egymásra szervezése.

\section{Gyakorlat bemutatása}

Re-ház (madárház, madáretető építés állattársaink számára)

Az újrahasznosítás, fenntarthatóság, környezet- és tájismeret a vizuális nevelésben.

\section{A gyakorlat müködtetöi}

A gyakorlat vezetői olyan vizuális- és környezetkultúra, földrajz szakterületen dolgozó pedagógusok, akik a tanári praxis során többször is észlelték a vizuális- és környezetkultúra tárgyon belül feszülő ellentmondáso- kat, egyenlótlenségeket. Az asszimetria a két terület, vizualitás és környezet által alkotott hierarchikus viszonyban figyelhetô meg. Ameddig az egyik részterület, a vizuális kultúra súlyozottan fejlesztendô a látni, ábrázolni tanítás által, addig a környezet ennek a tanulási folyamatnak az eszköze és legkevésbé sem a tárgya. Sajnálatos módon állapota, eltartóképessége, problémái vonatkozásában nem kerül feldolgozásra. A környezeti diskurzusokban instrumentalitásnak (Antal 2014), vagy tárgyiasításnak is nevezett emberi attitúd hagyományai a képzőművészetekben és általánosságban a vizuális nevelésben is megtalálhatóak. Egyrészt erre az antropocentrikus, ennél fogva fel- vagy, kihasználó attitúdre reflektálva, másrészt a korunkat keretező elméletekre, mint amilyen az antropocén (Crutzen, 2016) reagálva hívták életre a FeFe-t, azaz a Fenntartható Fejlődés Kurzust. Érzékenyen viszonyulva korunk környezeti, társadalmi történéseihez, tesznek kísérletet a komplexitás jegyében a tehetséggondozás, tanítás, nevelés egy alternatív formájára.

\section{A diákok összetétele, elóképzettsége}

A projektfeladat résztvevői egy múvészeti iskola 13. évfolyamos tanulói. A létszám 14 fö, ebből 9 fơ lány, 4 fő fiú. Szakmai tevékenységük osztályátlagban kifejezve 3,7. A legeredményesebb tanuló 4,5-ös átlaggal rendelkezik a csoportban leggyengébben teljesítő tanuló átlaga 2,3-2,5 között ingadozik.

Eddigi tanulmányaik során főként klasszikus rajzifestészeti (tanulmányrajzkészítés, kockológia, portré, félalak, festészet) feladatok megoldásával foglalkoztak, továbbá a szakiránynak megfelelően, alkalmazott grafikai (arculatterv, illusztráció, sokszorosító grafikai technológiák) szakmai feladatokkal.

\section{Célok}

- Kompreherzív és nem kivonó, szelektáló tehetséggondozási stratégia kidolgozása. Diákok lappangó, vagy eddig nem észlelt képességeinek monitorozása és fejlesztése. (Nahalka 2004)

- A gazdagon strukturált feladatok keretein belül komplexitásra törekvés, egymást tudatosan kiegészítő és támogató ismereteken keresztül divergens tanulási forma kialakítása. 
- Konvergens gondolkodás mellett a divergens problémanalízis gyakorlatának az elsajátítása. (Erdély 1998, Landau 1974)

- Iskolakert integrálása a projektfeladat kivitelezése során, helyi állatpopuláció feltérképezése céljából.

- Funkció és helyspecifikum orientált tervezési, kivitelezési gyakorlat, ami tárgy és produktumorientált ugyan, de nem klasszikus mútárgykészítés.

- A felhasználható anyagok kiválasztásában alapszempont a helyben, vagy természetben fellelhetőség, vagy újrahasznosítás, átalakítás, eltérítés az eredeti céltól.

- A tervezés és kivitelezés során építészeti szempontok figyelembevétele (szerkezet, stabilitás, installálhatóság, biztonság, funkció)

- A tervek gyakorlati kivitelezése során manuális és elektronikus kéziszerszám használata, és azok balesetvédelmi előírásoknak megfelelő alkalmazása.

- A re-házak, (madárházak, madáretetők) helyi madárfajok sajátosságainak megfelelô kialakítása.

- Kapcsolatfelvétel lokális szervezetekkel, intézményekkel a tárgyak számára leginkább alkalmas elhelyezés céljából.

\section{A gyakorlat részletes bemutatása}

- Kiindulópont a partneri pedagógus-diák viszonyrendszer tisztázása, mi, illetve mi nem várható el a csoport tagjaként, csoporttagként közremúködô pedagógusoktól. (jogok és kötelezettségek tisztázása a felek részérôl) Közös, részvételi alapon meghozott döntésekkel a feladat végleges meghatározása, a bedobott hívószavak felhasználásával. (mit, milyen módon, milyen eszközök alkalmazásával, milyen értékelési szempontrendszerek mentén). Munkaforma, ütemezés, részfeladatok meghatározása (individualizált, páros, vagy esetleg csoportos, időközi beszámolók időbeli elhelyezése a munkafolyamat aktuális állásáról).

- Ötletbörze, koncepciók rögzítése, azok megvalósíthatóságának mérlegelése a fellelhető, közösen meghatározott módon beszerezhető (újrahasznosított, készen talált, átalakítható, eltéríthető) anyagok, eszközök mennyiségének (természetes anyagok esetén mérsékelt felhasználás) és milyenségének (állat és környezetbarát) megfeleltetve. Végleges verziók kiválasztása, az ötletek folyamatos közzététele csoport előtti időközi prezentációk formájában.

- Helyismereti séta, városbarangolás, állandó és vonuló madárfajok monitorozása és anyagbeszerzés. Az Egerben adott, város terein fellelhető anyagok megismerése, feltérképezése, hasznosíthatósága a projekt során. Természetes anyagforrások (nád, bambusz) kapacitásának megállapítása, elkerülendő a túlfogyasztást. Kapcsolatteremtés a lakossággal, a feladatmegvalósításának céljából. (Kidobásra szánt háztartási, építkezési hulladék újrahasznosítása, beemelése a projektbe.) (1.kép)

\section{1.kép. Városi séta, anyagbeszerzés. (Forrás: Szzerzö)}

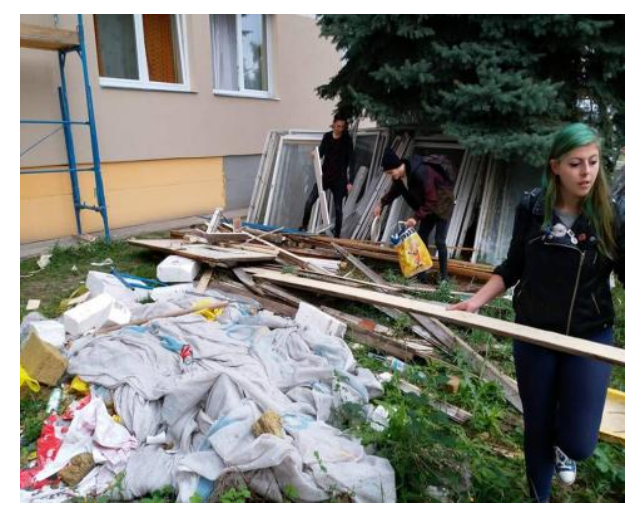

2. kép. Madárbáz tervrajza. (Forrás: Szerzó)

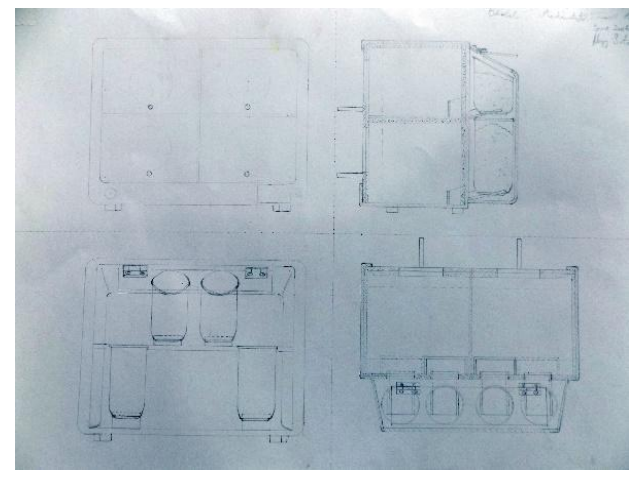

- Kivitelezési fázis az előre elkészített, méretarányos tervrajzok és színes látványtervek alapján. A hely-, illetve madárfaj specifikumnak megfelelő építészeti 
megoldásoknak megtartása és megvalósítása, a kiválasztott anyagok, kéziszerszámok felhasználásával. Az építés során használatos eszközök rövid balesetvédelmi szempontok szerinti ismertetése. Felhasznált eszközök: manuális, illetve elektronikus fűrészek, fúrógépek, csiszológépek, tưző és szögbelövő gépek, és egyéb kéziszerszámok. Lásd: 2. kép.

- A tárgyak bemutatása prezentáció formájában a csoport tagjai előtt, komplex önreflexió a teljes munkafolyamat figyelembevételével a tervek, prekoncepciók és kész tárgyak, kihívások, megoldott és megoldatlan problémák viszonylatában. Kapcsolatfelvétel a témában autentikus helyi szervezetekkel, intézményekkel a madárházak végleges elhelyezését illetően. Együttműködés a helyi madártani szövetkezettel, a madárházak elszállitása az Eszterházy Károly Egyetem Természettudományos Tanszékére, majd onnan a kijelölt befogadó intézményekhez történő végleges kihelyezése (óvodák, iskolák) (3.kép).

\section{3. kép. Madárbáz: (Forrás: Sžerzọó)}

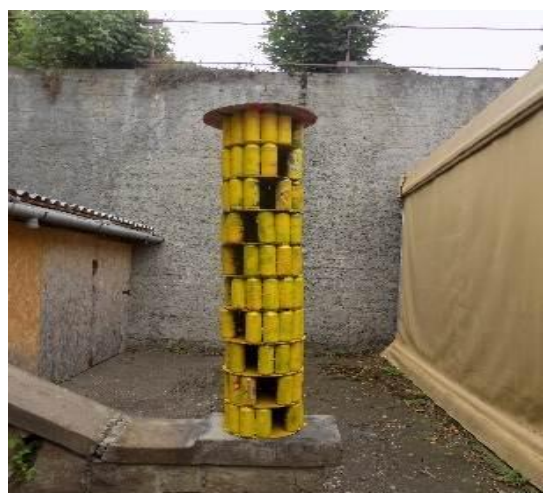

\section{Fejleszthetöség}

- Az intézmény szaktanárainak becsatornázása a további projektfeladatok megtervezésébe, kivitelezésébe. Az egyes tudományterületek tudatos összekapcsolása, az átjárási lehetőség maximalizálása tantárgy és tantárgy között. Törekvés a komplexitásra, transzdiszciplinaritásra.
- A divergens gondolkodás, ebből adódó divergens tanulási stratégia fejlesztése további projektfeladatok tervezésének, kivitelezésének céljából.

- Globalitás, lokalitás dichotómia megszűntetése. A világban múködő globális jelenségek artikulálása helyi szintű társadalmi, környezeti jelenségekben. A holizmus képének megteremtése. A helyünk és szerepünk fontosságának tudatosítása.

- Problémafelvetések aktualizálása, olyan időszerú társadalomtudományos, természettudományos elméleti keretrendszerek megismére, amelyek hozzájárulhatnak korunk megértéséhez, múködéséhez. (pl: technológiai szingularitás, online-offline létezés, virtualitás, médiaökológia)

- Az iskolakert lehetőségeinek fejlesztése. Nem területi, hanem funkcionális fejlesztés, kiteljesítés. Olyan pedagógiai elemek, célok hozzárendelése, amelyek által több gyakorlat végezhetô a külső iskolai helyszínen. (rekreáció, fejlesztőpedagógia, integráció, terápia)

- Hasonló, környezeti neveléssel, komplexitás élményével kapcsolatos nemzetközi kutatások monitorozása, eredmények kiértékelése, saját munkafolyamat, eredmények folyamatos összegzése, összevetése más kutatások eredményeivel. (Finnország, Dánia, Ausztrália)

- A virtualitás tudatos integrálása, internetes platform létrehozás közös gondolkodásra, gondolatok, ötletek tárolására és megosztására.

- Bekapcsolódás a helyi közösség életébe, kapcsolatfelvétel városi szervekkel, civil szervezetekkel, önkéntesekkel. Új ismeretek elsajátítása tapasztalati úton.

- A cselekvő szerepvállalás lehetôségének a növelése, bekapcsolódás városi ügyek (természeti, társadalmi) feltérképezésébe, megoldásába. Cselekvési kompetencia fejlesztése, cselekvési képesség tudatosítása.

\section{Eredmények, tapasztalatok}

Az klasszikus tárgyi követelményekkel, feladatokkal szemben (tanulmányrajz, színes kompozíció, kreatív feladatvégzés) a tanórai idókeretek között (2x45 perc, $4 \times 45$ perc) tanúsított (szórt, hullámzó) motiváltsághoz viszonyítva jelen esetben kimagasló aktív részvételi arány és egyenletes munkamorál volt megfigyelhetô a 
14 diák esetében a projekt kezdetétől egészen a befejezésig (16x45 perc).

A szakmai tudásuk, készségeik tekintetében heterogén összetételú társaság minden tagja megtalálta a projektfeladat végrehajtása során azokat a részterületeket, (számolás, méretre vágás, statikai-építészeti ismeretek, ornitológiai ismeretek, forrás és dokumentumelemzés) ahol a közösség hasznos tagjaként az egész részeként tudásának és képességének megfelelően járulhatott hozzá a tárgyak elkészítéséhez.

A tehetséggondozás ezen formája, amely nem, már meglévô képességek, hozott ismeretek alapján szelektál és hierarchizál kimutathatóan motiválóbb, továbbá általánosságban eredményesebb az eltérô szakmailag releváns és nem releváns képességgel rendelkező diákok körében.

A projektfeladatok prezentációját és közös kiértékelését követően kikérdezésre kerültek a tanulók a projekt alatt tapasztalat élményeiket, benyomásaikat illetôen. Ezek közül kiemelésre méltó az a több esetben (8válaszoló esetében) is olvasható vélemény, amely szerint különösen jó érzés volt valaminek az ügyében cselekedni, valóban megtenni valamit gyakorlatban és nem leképezni, színlelni azt.

Lévén, hogy alkalmazott művészeti képzésról beszélünk, fontos realizálni azt a tényt is, hogy a tárgy centrikus alkotói-kivitelezői aktus klasszikus iskolai koncepciója, végleges célját tekintve szintén meghaladható. A tárgyak, funkciójuk tekintetében tudnak izgalmasabbak lenni, mint dizájnos csomagba helyezett, gondolat- és érzelemébresztő (akár interaktív) hatásmechanimusok egy múteremben, vagy kiállítótérben. Gondos tervezés által megtalálható az a csatorna, amely kiszabadítja a tárgyakat (mútárgyakat) a rájuk szabott szûk értelmezési keretből, fizikai térből, és ez által passziv, befogadásra- interpretációra szoruló tárgyakból aktív, társadalmi hasznossággal bíró tárgyakká válnak a nyílt közösségi térben, iskolakertben a szükséges szakmai kritériumok teljes, vagy részleges betartása mellett is.

\section{Konklúzió}

Összegzésként a kitűzött célok és megvalósult eredmények összehasonlításában kijelenthető, hogy a fog- lalkozás újszerűségénének, integráló, aktív munkamódszerének köszönhetően a vártnál is pozitívabb fogadtatásban részesült a csoport tagjainak részéről. A környezet, természet, városi állatvilág helyzetével szemben látszólag közömbösséget mutató korosztály korán sem így viszonyul a kérdéshez. Továbbá fontos megemlíteni a cselekvést, mint valódi és nem szimulált részvételi lehetőséget a nyílt társadalmi térben, amely talán a legfőbb motivációs tényező a tanulók esetében.

\section{Irodalom}

Action Competence, Conflicting Interests and Environmental Education (2003) (olvasható: https://www.ucviden.dk/ws/files/10041047/Eng elst_udgave_af_MUVIN_bogen.pdf)

Crutzen, Paul (2016): A Pioneer on Atmospheric Chemistry and Climate Change in the Anthropocene, Springer, Svájc

Erdély Miklós (1991): Müvészeti irások, Képzőművészeti Kiadó, Budapest.

Gyarmathy Éva (2013): Tehetség és tehetséggondozás a 21. század elején Magyarországon. Neveléstudomány: oktatás - kutatás - innováció. 1 (2) 90-106.

Jensen B.B., Schnack K. (1997): The action competence approach in environmental education (olvasható: 2018.11.10. itt:

https://ensi.org/global/downloads/Publications/4 05/Jensen \%20Action \%20Competence\%20Approa ch\%20in\%20Environmental\%20Education.pdf)

Landau, Erika (1974): Kreativitás pszichológiája, Tankönyvkiadó vállalat, Budapest

Liebermann Mária (2009): A vizuális nevelés tantárgy tanitása az iskolarendszerü felnōttoktatásban (olvasható: 2018.11.10. itt:

http://ofi.hu/tudastar/kommunikacio/ vizualisneveles)

Mező Ferenc (2011): Tanulás: diagnosztike és fejlesztés az IPOO-modell alapján. $\mathrm{K}+\mathrm{F}$ stúdió Kft., Debrecen.

Nahalka István (2004): A komprehenziviv iskola breváriuma, SuliNova Közoktatás-fejlesztési és Pedagógustovábbképzési Kht., Budapest

Nemzeti Környezeti Nevelési Stratégia 2013 (2013), Kinizsi Nyomda, Debrecen 
Takács-Sánat András (szerk.) (2007): Paradigmaváltás ?!Kultúránk nébány alapvetö meggyóródésének újragondolása, L'Harmattan Kiadó, Budapest

Varga Tünde: Politikai ökológia és az antropocén nyilvános tér, beszélgetés Brian Holmes-szal (olvasható: 2018.
11.20. itt: http://tranzitblog.hu/politikai-okologiaes-az-antropocen-nyilvanos-ter/)

Vida Gábor (2012): Honnan hova Homo? Az antropocén korszake gondjai, Semmelweis Kiadó, Budapest 